\title{
Impact of Cluster Frontline Demonstration on Soybean Production in Tirap District of Arunachal Pradesh, India
}

\author{
Simanta Kumar Kalita ${ }^{1}$, D. S. Chhonkar ${ }^{1}$, P. P. Tripathi ${ }^{2}$ and Amit Kumar Singh ${ }^{1}$ \\ ${ }^{1}$ Krishi Vigyan Kendra, Tirap, Deomali, Arunachal Pradesh, India \\ ${ }^{2}$ Krishi Vigyan Kendra, East Kameng, Arunachal Pradesh, India \\ *Corresponding author
}

Ke y w o r d s
CFLD, Soybean,
Growth, Yield,
Production,
Improved practices,
Tirap
Article Info
$\begin{aligned} & \text { Accepted: } \\ & 15 \text { May } 2020 \\ & \text { Available Online: } \\ & \text { 10 June } 2020\end{aligned}$

\section{A B S T R A C T}

Soybean (Glysin max L.) is one of the most important oil seed cum pulse crop cultivated in Tirap district of Arunachal Pradesh. The production and productivity of soybean in the district is found to be low, therefore constant attempts are being made to improve the productivity and to increase the area under soybean by adopting high yielding variety along with improved cultivation practices. A total of 10 Cluster Frontline Demonstrations (CFLDs) at farmers' field were being carried out on soybean in 30 ha areas with 75 farmers to demonstrate production potential and economic benefits of improved practices comprising of high yielding variety JS - 9752 in Tirap District during kharif season 2018-19. Farmers obtained $23.7 \mathrm{q} / \mathrm{ha}$ soybean in demonstration plots which was 43.7 per cent higher yield than the farmer's practice ( $16.5 \mathrm{q} / \mathrm{ha}$ ). The average extension gap, technology gap and technology index were $7.2 \mathrm{q} / \mathrm{ha}, 1.3 \mathrm{q} / \mathrm{ha}$, and 5.2 per cent respectively. The improved practices gave highest gross return (Rs. 94,836/ha), net return (Rs. $59,589 / \mathrm{ha}$ ) and benefit cost ratio 2.69. It can be concluded that soybean production can be enhanced by encouraging farmers through adoption of improved technologies and providing need based inputs in due time which were followed in CFLDs.

\section{Introduction}

Soybean (Glycine $\max$ L.) belonging to family Leguminosae is one of the important oil seed crops of the world and has recognized as beneficial source of protein, edible oil and functional food. It is unique in the sense that large numbers of diverse end-products such as fortified soya flour, soya milk, tofu, biscuit, bread, products are made from it. According to the first advance estimates, Govt. of India, soybean production is estimated at 135.05 lakh tonnes during kharif 2019-20 from 113.98 lakh ha soybean cultivated area (Soybean Outlook, October'2019, Agricultural Market Intelligence Centre, PJTSAU). The problem is compounded by the fact that majority of the farmers in the rainfed regions were unaware of new and high yielding varieties and improved package of 
practices for cultivation. The productivity of crops per unit area could be increased by adopting improved practices in a systematic manner along with high yielding varieties (Ranawat et al., 2011; Rai et al., 2016). Frontline demonstration is an important tool to disseminate new technology at farmer's field. The constraints faced by the farmers in obtaining higher productivity is documented and the frontline demonstrations are designed to overcome the problems in a scientific way in order to show the worth of the new evolved variety and improved package of practices for enhancing the soybean productivity (Saravanakumar, 2018). Shaktawat et al., (2016) reported that majority of the marginal, small and large farmers belonged to low adoption category for seed treatment by fungicides and application of fertilizers, medium adoption for application of herbicide and plant protection measures of soybean production technology. Singh et al., (2014) concluded that training programmes backed by the field demonstrations proved to be the most effective tool for speedy dissemination of knowledge and technical skills to the farmers. Kaur et al., (2014) indicated that Front line demonstration program was effective in changing attitude of farmers towards pulse cultivation.

Generally farmers of Tirap district of Arunachal Pradesh grow local varieties of soybean (phidong) during May/ June and harvest in November/December with 160 days duration but the production and productivity is very less. To full fill the domestic requirement of oil, Indian government imports a huge quantity of oilseeds. In this regard, to sustain the production and consumption system, the Department of Agriculture, Co-operation and Farmers Welfare had sanctioned the "Cluster Frontline Demonstration on Kharif and Rabi oilseed 2018-19" to ICAR - ATARI Zone VI, Guwahati under National Food Security
Mission. To implement the project the Zone VI had selected KVK Tirap for soybean cultivation with an objective to boost the production and productivity of oilseed. To study the performance of short duration HYV of Soybean with 95-100 days duration (Variety : JS-9752) under proper management practices including seed treatment and integrated pest management was the prime objective.

\section{Materials and Methods}

The present investigation of CFLDs was conducted during kharif season 2018-19 by KVK Tirap, Arunachal Pradesh at Deomali and Khonsa subdivision under rainfed condition. An extensive survey was conducted to collect information from selected farmers to give them improved package of practice. Preferential ranking technique was utilized to identify the constraints faced by the farmers in soybean cultivation. The quantification of data was done by ranking the constraints and then calculating the Rank Based Quotient (RBQ) as given by Sabarathanam (1988), which is as follows:

$$
\mathrm{RBQ}=\frac{\sum \mathrm{fi}(\mathrm{n}+1-\mathrm{ith})}{\mathrm{N} \times \mathrm{n}} \times 100
$$

Wherein

fi $=$ number of farmers reporting a particular problem under $\mathrm{i}^{\text {th }}$ rank

$\mathrm{N}=$ Number of farmers

$\mathrm{n}=$ Number of problems identified

Based on the problems faced by the farmers, the cluster frontline demonstrations were designed. Scientific interventions under cluster frontline demonstrations were taken as mentioned in Table 1.

The extension gap, technology gap and technology index were calculated using the formula as suggested by Samui et al., (2000). 
Extension gap $(\mathrm{q} / \mathrm{ha})=\mathrm{DY}(\mathrm{q} / \mathrm{ha})-\mathrm{LY}(\mathrm{q} / \mathrm{ha})$ Technology gap $(q / h a)=P Y(q / h a)-D Y$ (q/ha)

Technology index $(\%)=$

$\frac{\text { Technology gap (q/ha) }}{\text { PY (q/ha) }} \times 100$

Wherein,

DY $=$ Demonstration Yield, LY = local Check Yield, PY $=$ Potential Yield of variety

The technology was demonstrated at ten different villages namely Noitong, Otongkhowa, Bera basti, New Subang, Sipini, Namsang, Mopya, Wasathong, Noksan and Natun Basti of the district that lies between the latitude $26^{\circ} 38^{\prime}$ to $27^{0} 47^{\prime} \mathrm{N}$, longitudes $96^{\circ} 16^{\prime}$ to $95^{\circ} 40^{\prime} \mathrm{E}$ and altitude $150-1200 \mathrm{~m}$ above MSL. As a whole, the soil of the demonstration site was sandy loam in texture, acidic in reaction ( $\mathrm{pH}$ 5.2), medium in organic carbon content $(0.75 \%)$, medium in available nitrogen content $(345 \mathrm{~kg} / \mathrm{ha})$, medium in available $\mathrm{P}_{2} \mathrm{O}_{5}(23.2 \mathrm{~kg} / \mathrm{ha})$ and low in available $\mathrm{K}_{2} \mathrm{O}(118.4 \mathrm{~kg} / \mathrm{ha})$. On an average the climate of the district is hot and humid at lower altitude and cold at upper altitude. The average annual rain fall of the district is $2520.00 \mathrm{~mm}$ with 139.54 rainy days. For this study total 75 farmers were selected in 30 ha area under 10 clusters (3 ha area under each cluster). The farmers were trained to follow the package and practices for scientific cultivation of soybean through on and off campus training, method demonstration, by distributing leaflets, group meeting and kisan gosthi, farmers scientist interactions and all the need based inputs provided to the farmers (Table 2). The farmers followed the full package and practices like soil testing, seed treatment with Rhizobium, fertilizer application, line sowing, weed management practices, integrated pest management. The seeds were treated with Rhizobium strain Majuli@12 g/kg seed by thorough mixing with its slurry and kept in shade for 5-6 hours before sowing. Seeds were sown in line at the spacing $30 \times 15 \mathrm{~cm}$ with seed rate $70 \mathrm{~kg} / \mathrm{ha}$. The required fertilizer was applied @ 20:60:40 kg N: $\mathrm{P}_{2} \mathrm{O}_{5}: \mathrm{K}_{2} \mathrm{O}$ per ha respectively. The traditional cultivation of soybean with their own varieties is considered as local check or farmers' practice. To study the impact of cluster frontline demonstrations, data from CFLD and farmers practices were analyzed.

\section{Results and Discussion}

\section{Constraints in soybean production}

Before conducting the CFLDs preferential ranking techniques were utilized to identify the constraints faced by the respondent farmers in soybean cultivation. The ranks given by different farmers are presented in Table 1. The findings indicate lack of suitable high yielding varieties $(82.57 \%)$, inadequate input availability $(77.35 \%)$, weed problem $(74.64 \%)$ and pest and disease problem $(64.67 \%)$ were the four major constraints. Similar findings were reported by Dupare et al., (2019), Sreelakshmi et al., (2012) and Arjunkumar et al., (2016). Based on the constraints, the cluster frontline demonstrations were conducted with high yielding soybean variety (JS-9752) and other major critical inputs for cultivation.

\section{Performance of CFLD}

The performance on growth parameters and yield data of newly introduced variety of soybean JS - 9752 along with improved practices was found better than the local check under same conditions and reported (Table 3 and Table 4). 
The data on growth parameters revealed that all the growth parameters were superior in CFLD plots to farmers' practice except plant height. Taller plant height $(88.74 \mathrm{~cm})$ was recorded at farmers' practice than CFLD plots $(78.76 \mathrm{~cm})$ which might be a varietal character of farmers' variety that leads to loadging due to wind and rain during harvesting stage resulted loss of yield and quality. More numbers of pods/plant recorded in CFLD plots (84.45 nos.) than farmers practice (46.79 nos.) which must be due to more numbers of primary branches per plant in CFLD plots.

Table.1 Ranks given by farmers for different constraints

\begin{tabular}{|l|l|l|c|}
\hline Sr.No. & Constraint & RBQ & Overall rank \\
\hline $\mathbf{1 .}$ & Lack of high yielding varieties & 82.57 & I \\
\hline $\mathbf{2 .}$ & Inadequate input availability & 77.35 & II \\
\hline $\mathbf{3 .}$ & Weed problem & 74.64 & III \\
\hline $\mathbf{4 .}$ & Pest and disease problem & 64.67 & IV \\
\hline $\mathbf{5 .}$ & Lack of technical knowledge & 60.00 & V \\
\hline $\mathbf{6 .}$ & Low soil fertility/problematic soil & 54.33 & VI \\
\hline $\mathbf{7 .}$ & Small and fragmented land holding & 51.67 & VII \\
\hline $\mathbf{8 .}$ & Labour shortage & 40.20 & VIII \\
\hline $\mathbf{9 .}$ & Low price of farm produce & 38.50 & IX \\
\hline $\mathbf{1 0 .}$ & Lack of post harvest management & 31.85 & X \\
\hline
\end{tabular}

Table.2 Details of need based inputs supplied to CFLDs of soybean

\begin{tabular}{|c|c|c|c|c|}
\hline Cluster & $\begin{array}{l}\text { Numbers of } \\
\text { demonstrations }\end{array}$ & Variety & $\begin{array}{l}\text { Technology } \\
\text { demonstrated }\end{array}$ & Need based input \\
\hline Noitong & 9 & \multirow[t]{10}{*}{ JS-9752 } & \multirow{10}{*}{$\begin{array}{l}\text { Improved } \\
\text { variety, Seed } \\
\text { treatment and } \\
\text { Line sowing }\end{array}$} & \multirow{10}{*}{$\begin{array}{l}\text { Improved seed (JS-9752), } \\
\text { Uniting together of small } \\
\text { land holder in a cluster of } \\
\text { big size, soil testing and } \\
\text { soil test based N, P, K } \\
\text { application, Rhizobium, } \\
\text { insecticide Malathion 50 } \\
\text { EC + Chloropyriphos 50\% }\end{array}$} \\
\hline Otongkhowa & 8 & & & \\
\hline Berabasti & 9 & & & \\
\hline New Subang & 8 & & & \\
\hline Sipini & 7 & & & \\
\hline Namsang & 7 & & & \\
\hline Mapaya & 9 & & & \\
\hline Wasathong & 7 & & & \\
\hline Noksan & 5 & & & \\
\hline Natunbasti & 6 & & & \\
\hline
\end{tabular}

Table.3 Growth parameters of cluster frontline demonstration on soybean

\begin{tabular}{|l|c|c|c|c|c|c|c|}
\hline Treatment & $\begin{array}{c}\text { Plant } \\
\text { height } \\
\text { (cm) }\end{array}$ & $\begin{array}{c}\text { Nos. of } \\
\text { primary } \\
\text { branch/ } \\
\text { plant }\end{array}$ & $\begin{array}{c}\text { Nos. of } \\
\text { pods per } \\
\text { plant }\end{array}$ & $\begin{array}{c}\text { Pod } \\
\text { length } \\
\text { (cm) }\end{array}$ & $\begin{array}{c}\text { Nos. of } \\
\text { seed } \\
\text { per } \\
\text { pod }\end{array}$ & $\begin{array}{c}\text { Days to } \\
\text { 50\% } \\
\text { flowering }\end{array}$ & $\begin{array}{c}\text { Pest and } \\
\text { disease } \\
\text { infestation }\end{array}$ \\
\hline CFLD plots & 78.76 & 10.68 & 84.45 & 6.5 & 4.33 & 65.52 & Less \\
\hline Farmers' practice & 88.74 & 5.2 & 46.79 & 5.2 & 4.0 & 87.63 & Medium \\
\hline
\end{tabular}


Table.4 Details of yield and economics of cluster frontline demonstration on soybean

\begin{tabular}{|l|c|c|c|c|c|}
\hline Treatment & $\begin{array}{c}\text { Yield } \\
\text { (q/ha) }\end{array}$ & $\begin{array}{c}\text { Gross Cost } \\
\text { (Rs./ha) }\end{array}$ & $\begin{array}{c}\text { Gross Return } \\
\text { (Rs./ha) }\end{array}$ & $\begin{array}{c}\text { Net Return } \\
\text { (Rs./ha) }\end{array}$ & B:C ratio \\
\hline CFLD plots & 23.7 & 35246 & 94836 & 59589 & 2.69 \\
\hline Farmers' practice & 16.5 & 26290 & 49500 & 23210 & 1.88 \\
\hline
\end{tabular}

Table.5 Yield, extension gap, technology gap and technology index of the demonstration

\begin{tabular}{|l|c|c|c|c|}
\hline Variables & Yield (q/ha) & $\begin{array}{c}\text { Extension gap } \\
(\mathbf{q} / \mathbf{h a})\end{array}$ & $\begin{array}{c}\text { Technology } \\
\text { gap (q/ha) }\end{array}$ & $\begin{array}{c}\text { Technology } \\
\text { index (\%) }\end{array}$ \\
\hline CFLD plots & 23.7 & 7.2 & 1.3 & 5.2 \\
\hline Farmer's practice & 16.5 & & & \\
\hline
\end{tabular}

Less numbers of days to flowering (65.52 days) was recorded at CFLD plots than farmers' practice (87.63 days) which is a varietal character of JS-9752. Less pest and disease incidence was recorded at CFLD plots due to adoption of appropriate management practices in comparison to farmers' practice. This confirms the findings of Kalita et al., (2019) on pigeon pea cultivation.

Regarding yield and economics, result concluded that highest yield (23.7 q/ha) was recorded in demonstration plots than farmers' practice $(16.5 \mathrm{q} / \mathrm{ha})$ with $43.7 \%$ higher yield over the farmer practice. Superior growth parameter like more primary branches and pods per plant was the reason for higher yield which was due to combined effect of seed treatments, application of fertiliser, timely intercultural operations and integrated pest diseases management practices in CFLD plots. Similar findings was also reported by Rai et al., (2016) and Kalita et al., (2019). The economic feasibility of improved practices over farmer practices was calculated depending upon the prevailing prices of inputs and output cost and gross return (Rs.94,836), net return (Rs. 59,589) and benefit cost ratio (2.69:1) was found superior in CFLD plots to farmer's practice. Hence, improved production technologies in soybean have the broader scope for increasing the productivity per unit area. These results confirmed the findings of Khedkar et al., (2017).

Yield of cluster frontline demonstration plots and potential yield of the crop was compared to estimate the yield gap, further it was categorized into extension gap, technology gap and technology index (Table 5.). The extension gap and technology gap were 7.2 and $1.3 \mathrm{q} /$ ha respectively. The extension gap and technology gap observed may be attributed due to dissimilarities in soil fertility levels, pest and disease incidence, improper usage of manures and fertilizers in the district. Hence, to narrow down the yield gaps location specific technologies needs to be adopted. Technology index shows the feasibility of the variety at the farmers' field and it was reported 5.2 percent. The findings of the present study were in line with the findings Saravanakumar (2018).

In conclusion, potential yield of variety can be achieved by imparting scientific knowledge to the farmers, providing need based quality inputs in due time and proper and timely application of inputs. The horizontal spread of improved technology might be achieved by successful 
implementation of CFLDs and by various extension activities like training, organizing field day, field visit, kisan gosthi, group meeting and exposure visit of nearby farmers to CFLD plots. Training to extension functionaries under District Agricultural Offices is essential for rapid dissemination of the technology to the entire district. It can be concluded that newly introduced variety of soybean along with improved package of practices performed well in the Tirap district of Arunachal Pradesh and adoption is also appreciable among the farmers.

\section{References}

Arjunkumar, V., Lal, J. K., Ram J. and Chand, N. K. 2016. Popularization of high yielding varieties of wheat (Triticum aestivum L.) in Jhalwar district of Rajasthan state through frontline demonstrations. Journal of Wheat Research 8(1): 39 - 44.

Dupare, B. U., Billore, S. D. and Joshi, O. P. 2019. Identification of Problems of Soybean Growers in Madhya Pradesh. Indian Journal of Extension Education. 45 (3 \& 4): 102-105.

Kalita, S., Chaturvedi, A., Singh, A. K. and Ghosh, C. 2019. Role of Cluster Frontline Demonstration on Arahar Production in Tirap District of Arunachal Pradesh. Satsa Mukhapatra-Annual technical issue. 23: 159-163.

Kaur, P., Kaur, A., Kaur, B. and Singh, K. 2014. Performance of Front Line Demonstrations on Summer Moong in Jalandhar district. Journal of Krishi Vigyan 3(1): 58-61.

Khedkar, R., Shinde, V. and Chaudhari, P. 2017. Role of cluster frontline demonstration in enhancement of chickpea production. Journal of Krishi Vigyan 6 (1): 172-174.

Rai, A. K., Khajuria, S., Lata, K., Jadhav, J.,
Rajkumar, K. and Khadda, B. S. 2016. Popularization of vegetable pigeon pea (Cajanus cajan) in central Gujarat through demonstration in farmers field. Indian Journal of Agricultural Science. 85 (3): 349-353.

Ranawat, Y., Ram, H., Sisodiya, S. S. and Punjabi, N. K. 2011. Adoption of improved maize cultivation practices by trained and untrained farmers of KVK, Udaipur. Rajasthan Journal of Extension Education 19: $144-147$.

Sabarathanam, V. E. 1988. Manuals of field experience training for ARS Scientists. NAARM, Hyderabad.

Samui, S. K., Mmaitra. S., Roy, D. K., Mondal, A. K. and Saha, D. 2000. Evaluation of frontline demonstration on groundnut (Arachis hypogaea L,) in Sundarbans. Indian Society of Coastal Agricultural Research. 18 (2): 180-183.

Saravanakumar, S. 2018. Impact of Cluster Frontline Demonstration on Black gram in Western Zone of Tamilnadu. Journal of Krishi Vigyan. 7(1) : 136-139.

Shaktawat, R. P. S., Somvanshi, S. P. S. and Singh, D. 2016. Study on Adoption of Production Technology of Soybean by Farmers in Mandsaur District of Madhya Pradesh. Journal of Krishi Vigyan 5(1) : 104-106.

Singh, A. P., Vaid, A. and Mahajan, V. 2014. Impact of KVK Training Programmes and Frontline Demonstrations on Adoption of Pusa Basmati 1121 in Kathua district of Jammu and Kashmir. Journal of Krishi Vigyan 2 (2): 44-48.

Sreelakshmi, C. H., Kumar, S. C. V. and Shivani, D. 2012. Productivity enhancement of Pigeon pea (Cajanus canjan L.) through improved production technology. Madras Agricultural Journal. 99 (4-6): 185-189.

\section{How to cite this article:}

Simanta Kumar Kalita, D. S. Chhonkar, P. P. Tripathi and Amit Kumar Singh. 2020. Impact of Cluster Frontline Demonstration on Soybean Production in Tirap District of Arunachal Pradesh, India. Int.J.Curr.Microbiol.App.Sci. 9(06): 732-737. doi: https://doi.org/10.20546/ijcmas.2020.906.093 